\title{
Разработка комплексной оценки белкового состава молока сырья различных сельскохозяйственных животных для выработки продуктов функциональной направленности
}

\author{
Мельденберг Дарья Николаевна \\ ФГАНУ «Всероссийский научно-исследовательский институт молочной промышленности» \\ Адрес:115093, город Москва, ул. Люсиновская, д.35, корп.7 \\ E-mail:d_meldenberg@vnimi.org
}

Полякова Ольга Сергеевна ФГАНУ «Всероссийский научно-исследовательский институт молочной промышленности» Адрес:115093, город Москва, ул. Люсиновская, д.35, корп.7

E-mail:o_polyakova@vnimi.org

Семёнова Елена Сергеевна ФГАНУ «Всероссийский научно-исследовательский институт молочной промышленности» Адрес:115093, город Москва, ул. Люсиновская, д.35, корп.7

E-mail: __semenova@vnimi.org

Юрова Елена Анатольевна ФГАНУ «Всероссийский научно-исследовательский институт молочной промышленности» Адрес:115093, город Москва, ул. Люсиновская, д.35, корп.7

E-mail:e_yurova@vnimi.org

\begin{abstract}
В последнее время значительный интерес приобретает производство пищевой продукции с повышенной биологической ценностью, с новыми составными ингредиентами и функциональными характеристиками, обусловленными как составом компонентов, так и применяемым сырьем. Для производства такой продукции требуется подбор оптимального молочного сырья с обязательной оценкой количества белка, его состава и полноценности, что было осуществлено в данной работе, где рассматривалось молоко сырье разных сельскохозяйственных животных. В ходе выполнения работы в качестве методов исследований применяли как общепринятые и стандартизованные методики измерений, так и усовершенствованные, в частности для определения аминокислотного состава применяли метод капиллярного электрофореза (КЭФ). По результатам исследований установлена зависимость содержания массовой доли белка от содержания небелковых азотистых веществ, истинного белка, незаменимых и заменимых аминокислот. Отмечена необходимость определения истинного белка для учета полноценности белка готового продукта. Установлено, что при пересчете количества аминокислот мг/1г на содержание истинного белка, то количество незаменимых и заменимых аминокислот пропорционально увеличивается на 1,05-1,08\% в сравнении с пересчетом на содержание общего белка, то есть неучтенным остается примерно 1г полноценного молочного белка.
\end{abstract}

Ключевые слова: молоко сырое, массовая доля белка, небелковый азот, истинный белок, аминокислотный состав, аминокислотный скор, биологическая ценность, функциональные свойства

\section{Введение}

В современном мире остро встает вопрос о дефиците сырья, полностью обеспечивающего потребности организма человека в белке и незаменимых аминокислотах. В целях обеспечения выполнения распоряжения Правительства Российской
Федерации №1873-р от 25.10.2010 г «Основы государственной политики Российской Федерации в области здорового питания населения на период до 2020 года», одной из первостепенных задач является разработка и создание функциональных продуктов питания, в том числе и продуктов белковой направленности. 
Так как белок выполняет основную структурную функцию в организме человека и в отличие от жиров и углеводов не депонируется, организму требуется постоянное потребление сбалансированных по белковому составу продуктов питания (Лысиков, 2012, с. 88-105; Рудаков, Рудакова, 2019, с. 32-35).

Для решения данной проблемы во всем мире проводится ряд мероприятий, направленных на получение сырья и производство продукции функциональной направленности с полноценным белком. Научные разработки ведутся в следующих направлениях:

- селекционная работа по подбору видов сельскохозяйственных животных и их продуктивности;

- составление кормовых рационов;

- подбор сырья и изучение его функциональных свойств;

- составление рецептур с учетом получения в составе готового продукта рекомендованного количества полноценного белка;

- разработка и применение высокотехнологических процессов производства функциональных продуктов, направленных на минимизацию белковых потерь и сохранение их биологической (пищевой) ценности.

\section{Литературный обзор}

В последние годы появился интерес к применению при производстве пищевых продуктов функциональной направленности молока других сельскохозяйственных животных помимо коровьего, что связано в первую очередь с увеличением количества ферм и объемов производимого молока (по данным FAOSTAT объем производимого козьего молока увеличивается ежегодно на 5-10\%, а овечьего по сравнению с 2013г увеличилось в 3 раза), а также с доказанными лечебными свойствами и особенностью состава молока козьего, а также овечьего, кобыльего и верблюжьего (Шувариков, Пастух, Жукова, Жижин, 2019, с. 130-148; Юрова, Семенова, Мельденберг, Канина, Робкова, 2017, с. 60-63; Шувариков, Хататаев, Пастух, Робкова, Семенова, Коробейник, 2019, c. 30-32). Данный факт позволяет рассматривать применение молока других сельскохозяйственных животных в качестве ингредиента при производстве продуктов функциональной направленности (Донская, 2007, с. 52-53; Зобкова, 2018, с. 75-76; Зобкова, Фурсова, Зенина, 2018, с. 64-69). Также прослеживается тенденция роста использова- ния козьего молока при производстве продуктов детского, лечебно-профилактического питания и сыров (Бахтиярова, 2016, с. 96-99; Асембаева, Галстян, Хуршудян, Нурмуханбетова, Велямов, Аленова, Сейдахметова, 2017, с. 67-73).

По данным многочисленных исследований именно белки молока обладают функциональными свойствами и по этой причине находят широкое применение в пищевой промышленности (Augustin, Udabage, 2007, p.1-38; Singh, 2011, p. 887-893; Mattila-Sandholm, Saarela, 2003, p. 1113; Агаркова, Кручинин, Рязанцева, Пряничникова, 2019, с. 81-88). Особый интерес представляют исследования составных частей молочного белка, в том числе аминокислотного состава, молекулярно-массового распределения его фракций и их соотношений, содержания свободных аминокислот, поскольку белки обеспечивают организм всеми необходимыми незаменимыми аминокислотами (Донская, 2007, с. 52-53; Dziuba B., Dziuba М., 2014, p. 5-26).

Также одной из основных задач современной технологии переработки молока является сохранение свойств белка молочного сырья, что позволяет обеспечить свойства, состав, определенную структуру, технологические и потребительские свойства конечного продукта ${ }^{1}$ (Федотова, Донская, Рожкова, Асафов, Добриян, Чумакова, 2016, с. 15-18; Kinsella, Melachouris, 1976, p. 219-280; Фильчакова, Медведев, Тамбовцев, 2006, с. 42-44).

Известно, что основным функциональным макронутриентом молока сырья является белок, чьи свойства тесно связаны с его строением, физико-химическими характеристиками и биологическими функциями, в том числе и высокой пищевой ценностью ${ }^{1}$ (Агаркова, Кручинин, Рязанцева, Пряничникова, 2019, с. 81-88).

Применение пищевых белков в качестве функциональных ингредиентов оказывает влияние на улучшение структуры пищевых продуктов и константность при переработке (Молчанова, Суслянок, 2013, с. 16-22).

Функционально-технологические свойства молочных белков можно разделить на две основные группы (Augustin, Udabage 2007, p. 1-38; Singh, 2011, p. 887-893; Mattila-Sandholm, Saarela, 2003, p. 11-13):

- гидродинамические или связанные с гидратацией, которые включают водосвязывающую

\footnotetext{
Демирова А.Ф., Исригова Т.А. Производство функциональных продуктов питания: учеб. пособие. Махачкала, 2015. 180 с.
} 
способность, растворимость, вязкость и гелеобразование;

- технологические - эмульгирование, вспенивание и пленкообразование, связанные с поверхностно-активными свойствами белков.

Молочные белки могут проявлять и несколько функциональных свойств одновременно, что позволяет расширять возможности последующего их применения в пищевой промышленности (Фильчакова, Медведев, Тамбовцев, 2006, с. 42-44; Singh, 2011, p. 887-893; Кручинин, Агаркова, 2018, с. 36-39; Юрова, Денисович, Кобзева, Мельденберг, Семёнова, Жижин, Пахомова, 2019, с 50-53; Галстян, Аксёнова, Лисицын, Оганесянц, Петров, 2019, с. 539-542; Федотова, Донская, Рожкова, Асафов, Добриян, Чумакова, 2016, с. 15-18). При этом необходимо учитывать тот факт, что свойства молочных белков варьируются в зависимости от различных факторов, в том числе от активной кислотности (pH), температуры, концентрации ионов, содержания кальция, сахаров и гидроколлоидов, а также влияния параметров технологической обработки (Kinsella Melachouris, 1976, p. 219-280; Singh, 2011, p. 887-893).

В ГОСТ Р 52054-2003 (Изменение № 2)², установлены новые критерии оценки молока коровьего сырого: «Содержание небелкового азота и истинного белка, расчет которого является разность между массовой долей общего азота и небелкового азота, умноженная на коэффициент 6,38». Данные критерии оценки позволяют установить «технологичный» белок, т.е. тот белок, который в процессе производства не разрушается, что позволяет прогнозировать качество готового продукта (Юрова, Семенова, Мельденберг, Канина, Робкова, 2017, с. 50-53; Юрова, Кобзева, Полякова, 2016, c. $38-41)$.

Получение новых данных об интеграции молочных белков с микро- и макронутриентами сложных многокомпонентных пищевых систем, к которым относятся функциональные продукты, выработанные на молочной основе дает понимание природы их взаимодействия и позволяет оценить степень его влияния на качество готового продукта (Зобкова, 2007, с. 75-76).

Особое внимание при исследовании свойств молока сырья, применяемого в качестве основного компонента при производстве функциональных продуктов белковой направленности, следует уделить не только количеству белка, но и его полноценности, то есть, сбалансированности аминокислотного состава. Дефицит или переизбыток отдельных аминокислот может приводить к необратимым нарушениям работы органов и их систем, а также вызывать патологические изменения в организме человека, особенно опасные в раннем возрасте (Нечаева, Друк, Лялюкова, 2013, с. 23-26; Литвицкий, Мальцева, 2015, с. 95-107). Потребление в пищу несбалансированных по белковому составу продуктов может привести к нарушению белкового обмена и как следствие к развитию заболеваний различной этиологии, связанных со сбоем работы органов и систем всего организма (Рудаков, Рудакова, 2019, с. 32-35).

В качестве индикаторного показателя белкового обмена принято считать азотистый баланс, представляющий собой разность между потребляемым и выделяемым организмом человека количеством азота. Выделяют три вида азотистого баланса:

- нулевой, характерный для взрослого здорового организма, при котором потребляемое и выводимое количество азотистых соединений находится в равном соотношении;

- положительный, где количество поступившего азота превышает выводимый. Такой баланс считается нормой для детей и взрослых в период беременности и регенеративный период, но может являться и патологией при сопутствующих заболеваниях;

- отрицательный, при котором количество поступающего азота, ниже отводимого организмом. Причинами возникновения могут стать длительное голодание, стрессы, тяжелая форма сахарного диабета и т.п. (Литвицкий, Мальцева, 2015, с. 95-107).

Существует несколько видов нарушений белкового и аминокислотного обмена в организме человека, одним из которых является непропорциональность количества белков и аминокислот, поступающих в организм к его потребностям. Установлено, что суточное количество потребления, требующееся организму человека для восполнения общего расхода белка и необходимого количества незаменимых аминокислот, находится в пределах 1,5-2,5 г на 1 кг массы тела 3 (Мальцева, 2015, c. 95-107; Kinsella, Melachouris, 1976, p. 219-

ГОСТ Р 52054-2003. Молоко натуральное коровье - сырье. Технические условия. М.: Стандартинформ, 2008.16 с.

3 MP 2.3.1.2432-08. Нормы физиологических потребностей в энергии и пищевых веществах для различных групп населения Рос. Федерации / утвержденные 18.12.2008 главным санитарным врачом Рос. Федерации Г.Г. Онищенко. Москва, 2008. 39 с. 
280). Нехватка поступающего в организм белка, в комплексе с минеральными веществами и углеводами необходимыми для его полноценного усвоения может привести к белково-энергетической недостаточности, которая в свою очередь влечёт за собой развитие целого ряда заболеваний, в том числе наследственных, таких как квашиоркор, алиментарная дистрофия и т.п. (Нечаева, Друк, Лялюкова, 2013, с. 23-26; Литвицкий, Мальцева, 2015, c. 95-107).

Одним из наиболее распространенных заболеваний, связанных с нарушением аминокислотного обмена, является фенилкетонурия, обусловленная дефицитом фенилаланина-4-гидроксилазы фермента, обеспечивающего переход фенилаланина в тирозин (Бушуева, 2010, с. 157-160; Малиновский, 2011, с. 116-119; Литвицкий, Мальцева, 2015, с. 95-107). Данное утверждение позволяет сделать вывод, что потребность организма в полноценном белке обеспечивает полный аминокислотный состав продуктов питания или биологическую (пищевую) ценность. Для установления биологической (пищевой) ценности белка применяют химические и биологические (с применением животных и микроорганизмов) методы исследований (Хамагаева, Хараев, Жеребятьева, Щёкотова, 2015, с. 72-77; Рудаков, Рудакова, 2019, с. 32-35).

Наиболее доступным методом оценки биологической ценности продуктов питания является метод определения аминокислотного скора (scor - счёт, подсчёт), который рассчитывают по формуле (1) (Липатов, 1990, с. 5-10; Липатов, Рогов, 1987, с. 9-15; Образов, Надточий, Сафронова, 2019, c. 447-453):

$$
A C=\frac{A K_{n p}}{A K_{u \sigma}} 100,
$$

где: АC - аминокислотный скор, \%; $A K_{\text {пр }}$ - содержание любой незаменимой аминокислоты в 1 г белка исследуемого продукта, мг; $A K_{\text {иб }}$ содержание любой незаменимой аминокислоты в 1 г стандартного (эталонного, «идеального») белка, мг.

Эталонный белок представляет собой идеально сбалансированный по аминокислотному составу теоретический белок, в котором скор по каждой из незаменимых аминокислот по данным утвержденным ФАО/ВОЗ в 1973г и уточненным в 1985 г, а позднее в 2007 г и 2011г равен 100\% (FAO Food and Nutrition Paper 92, 20134). С учетом погрешности (неопределенности) методов испытаний, составляющих от 5 до 10\% относительности полноценным принято считать белок, скор аминокислот которого равен 95\% и более (Лепешкин, Надточий, Чечеткина, 2020; CAC/GL 4-1989; FAO Food And Nutrition Paper ${ }^{5}$ ).

Аминокислоту с самым низким скором принято называть лимитирующей (лат. Limitus - граница) именно она определяет степень усвоения белка организмом, так как аминокислоты со скором

Таблица 1

Аминокислотный состав и аминокислотный скор стандартного (эталонного) белка, рекомендуемый ФАО/ BO3 (CAC/GL 4-1989; FAO Food And Nutrition Paper 92, 2013)

\begin{tabular}{lcc}
\hline \multirow{2}{*}{ Наименование аминокислоты } & Эталонный белок, г аминокислоты в 100 г белка (2011г) \\
\cline { 2 - 3 } & $A^{*}$ & $A C^{* * *}$ \\
\hline Гистидин & 2,0 & 100 \\
Изолейцин & 3,2 & 100 \\
Лейцин & 6,6 & 100 \\
Лизин & 5,7 & 100 \\
Метионин + цистиннж** & 2,7 & 100 \\
Фенилаланин + тирозин ${ }^{* * * *}$ & 5,2 & 100 \\
Треонин & 3,1 & 100 \\
Триптофан & 0,85 & 100 \\
Валин & 4,3 & 100 \\
\hline
\end{tabular}

${ }^{4}$ Dietary protein quality assessment in human nutrition: report of an FAO Expert Consultation March 31 - April 2, 2011. Auckland, 2013. 68 P. URL: http://www.fao.org/3/a-i3124e.pdf (дата обращения: 04.08.2020).

5 CAC/GL 4-1989. General Guidelines For The Utilization Of Vegetable Protein Products (VPP) in Foods. URL: http://www.fao.org/faowho-codexalimentarius/codex-texts/guidelines/en/ (дата обращения: 04.08.2020). 
значительно превышающим лимитирующую не используются в биосинтезе белка и не депонируются в организме человека (Липатов, 1990, с. 5-10; Литвицкий, Мальцева, 2015, с. 95-107).

Значения аминокислотного состава эталонного («идеального») белка представлены в Таблице 1.

Учитывая все вышеизложенное можно сделать вывод, что для подбора сырья, применяемого при производстве продуктов функциональной направленности необходимо проводить комплексное исследование его белкового состава, с учетом полного аминокислотного состава и расчетом биологической ценности белка.

\section{Теоретическое обоснование}

Оценка функциональных возможностей белков остается важной частью исследований молочных продуктов функциональной направленности и особенно это актуально при разработке новых видов молочной продукции, в том числе выработанных с применением различного молочного сырья. Разработка и применение новых методов оценки белкового состава позволит оценить не только состав продукта и его биологическую ценность, но и вклад белков в функциональные свойства (Kristo, Corredig, 2015, p. 47-73; Zdzislaw, 2001; Бабич, 2009).

Получение новых достоверных данных при исследовании физико-химических свойств белков молока позволит прогнозировать состав и свойства готового продукта функциональной направленности и решить задачу сохранения свойств и составных частей белка молока сырья (Wilding, Lillford, Regenstein, 2008, p. 182-189; Zdzislaw, 2001).

Разработка методологии оценки изменений функциональных свойств белков позволила бы повысить полезность многих нетрадиционных источников белка и расширить возможности технологии переработки молочного сырья. В качестве методических подходов оценки функциональных свойств пищевых белков целесообразно использовать состав белка, включая аминокислотный и фракционный состав с учетом общего и небелкового азота. Понимание состава белка, его структуры, механизмов структурообразования биополимеров и др. должно привести к более глубокому пониманию основы функциональности продукта (Ryan,1977, p. 6791; Zdzislaw, 2001 ).

Целью данных исследований являлась разработка комплексной оценки белкового состава молока сырья различных с/х животных, как основы для выработки продуктов функциональной направленности.

Для реализации поставленной цели были определены следующие задачи:

- $\quad$ провести исследования молока сырья различных видов c/х животных по содержанию массовой доли белка, небелкового азота, белков сывороточной и казеиновой фракций, массовой доли истинного белка, аминокислотному составу;

- определить характеристики полноценности белка применительно к продуктам функциональной направленности с учетом аминокислотного скора;

- рассчитать биологическою ценность молочного белка

\section{Материалы и методы исследования}

Объектами исследований являлось молоко сырое: коровье, козье, овечье, кобылье.

Для определения белкового состава применяли следующие методы анализа:

- массовую долю белка и общего азота (OА) определяли методом Кьельдаля в соответствии с ГОСТ 23327-986;

- содержание сывороточных белков (СБ) по ГОСТ 34536-20197;

- содержание небелкового азота (НБА) по ГОСТ Р 55246-2012

- содержание казеиновых белков (КБ) методом Кьельдаля по СТБ ISO 17997-1-20129;

6 ГОСТ 23327-98. Молоко и молочные продукты. Метод измерения массовой доли общего азота по Кьельдалю и определение массовой доли белка. М.: Стандартинформ, 2009. 11 с.

ГОСТ 34536-2019. Молоко и молочная продукция. Определение массовой доли сывороточных белков методом Кьельдаля. М.: Стандартинформ, 2019. 19 с.

8 ГОСТ Р 55246-2012. Молоко и молочные продукты. Определение содержания небелкового азота с применением метода Кьельдаля. М.: Стандартинформ, 2013. 14 с.

9 CTБ ISO 17997-1-2012. Молоко. Определение содержания казеинового азота. Ч. 1. Косвенный метод (арбитражный метод). Минск: Госстандарт, 2004. 11 с. 
- $\quad$ расчет массовой доли истинного белка (ИБ) осуществляли по ГОСТ Р 52054-2003 ${ }^{10}$ (Изменение №2);

Исследования проводили с применением следующего оборудования:

- для минерализации проб использовали дигестор SH220F с системой отвода паров серной кислоты WD03 (фирмы Наnon, Китай). Максимальная температура нагрева $450^{\circ} \mathrm{C}$;

- для отгонки аммиака использовали полуавтоматическую систему дистилляции К9840 (фирмы Hanon, Китай);

Содержание аминокислотного состава осуществляли методом капиллярного электрофореза (КЭФ). Данный метод определения аминокислот основан на предварительном кислотном и щелочном (только для триптофана) гидролизе, с целью перевода аминокислот в свободные формы, получении фенилизотиокарбамильных производных, дальнейшем их разделении и количественном определении методом капиллярного электрофореза. Исключение составляет триптофан, при его определении использовали прямое детектирование, которое проводили на оборудовании «Капель - 205» (Люмекс, Россия) в УФ - области спектра при длине волны 254 нм, с использованием кварцевого капилляра, внутренний диаметр которого 50 мкм и общая длина 75 см, объем пробы составлял $2,5 \mathrm{~cm}^{3}$.

По всем исследованным показателям испытания проведены в двух повторностях на массиве образцов: молоко коровье - 150 проб, молоко козье - 86 проб, молоко овечье - 39 проб, кобылье молоко- 22 пробы.

\section{Результаты исследований и их обсуждение}

В ходе проведения исследований был изучен белковый состав молока сырого разных сельскохозяйственных животных с учетом расчетной величины истинного белка (Таблица 2).

Сравнительный анализ белкового состава молока разных видов сельскохозяйственных животных показал, что самое низкое значение массовой доли белка у кобыльего молока 2,26\%, а самое высокое содержание отмечено у овечьего молока - 5,16\%. Также было отмечено, что значение массовой доли истинного белка (ИБ) является наиболее объективной величиной по сравнению с массовой долей белка в целом. Если принять весь белок в молоке за 100\%, то разность между значениями массовой доли общего белка и массовой долей истинного белка в процентном соот-

Таблица 2

Состав молока сырого различных видов сельскохозяйственных животных

\begin{tabular}{|c|c|c|c|c|}
\hline \multirow[t]{2}{*}{ Наименование показателя } & \multicolumn{4}{|c|}{ Фактическое значение } \\
\hline & $\begin{array}{c}\text { Молоко } \\
\text { коровье сырое }\end{array}$ & $\begin{array}{c}\text { Молоко } \\
\text { козье сырое }\end{array}$ & $\begin{array}{c}\text { Молоко } \\
\text { овечье сырое }\end{array}$ & $\begin{array}{c}\text { Молоко } \\
\text { кобылье сырое }\end{array}$ \\
\hline Массовая доля белка, \% & $3,37 \pm 0,09$ & $3,76 \pm 0,09$ & $5,16 \pm 0,11$ & $2,26 \pm 0,06$ \\
\hline Содержание общего азота, \% & $0,528 \pm 0,006$ & $0,586 \pm 0,007$ & $0,809 \pm 0,008$ & $0,354 \pm 0,006$ \\
\hline $\begin{array}{l}\text { Содержание небел- } \\
\text { кового азота, \% }\end{array}$ & $0,032 \pm 0,003$ & $0,042 \pm 0,003$ & $0,058 \pm 0,003$ & $0,017 \pm 0,003$ \\
\hline $\begin{array}{l}\text { Массовая доля истин- } \\
\text { ного белка, \% }\end{array}$ & $3,16 \pm 0,06$ & $3,47 \pm 0,06$ & $4,79 \pm 0,06$ & $2,15 \pm 0,06$ \\
\hline $\begin{array}{l}\text { Содержание сыворо- } \\
\text { точных белков, \% }\end{array}$ & $0,82 \pm 0,05$ & $1,0 \pm 0,07$ & $1,39 \pm 0,08$ & $1,08 \pm 0,07$ \\
\hline $\begin{array}{l}\text { Содержание казеи- } \\
\text { новых белков, \% }\end{array}$ & $2,57 \pm 0,04$ & $2,78 \pm 0,08$ & $3,79 \pm 0,07$ & $1,17 \pm 0,07$ \\
\hline $\begin{array}{l}\text { Соотношение казеиновых бел- } \\
\text { ков и сывороточных белков, \% } \\
\text { от общего количества белка }\end{array}$ & $72,3 / 23,7$ & $73,9 / 26,1$ & $73,4 / 26,9$ & $51,8 / 47,8$ \\
\hline
\end{tabular}

10 ГОСТ Р 52054-2003. Молоко коровье сырое. Технические условия. М.: Стандартинформ, 2004. 16 с. 
ношении составила 6,1\% для коровьего молока, 7,7\% для козьего, 7,2\% для овечьего и 0,6\% для кобыльего молока. Поэтому при расчете пищевой и биологической ценности молочных продуктов, а особенно продуктов функциональной направленности целесообразно учитывать именно массовую долю истинного белка, фактически ответственную за технологические свойства системы.

Результаты, представленные в Таблице 2 показывают, что соотношение казеиновых белков к сывороточным белкам в молоке коровьем, козьем и овечьем составило приблизительно 3:1, а в кобыльем примерно 1:1.

Результаты исследования полного аминокислотного состава молока сырья разных видов с/х животных приведены на Рисунках 1 и 2.

По полученным результатам (Рисунок 1) состав незаменимых аминокислот кобыльего молока существенно отличается от молока других видов c/x животных, что в первую очередь обусловлено изначально низким содержанием белка. В частности, отмечено снижение на 50-70\% практически по всем незаменимым аминокислотам по сравнению с коровьим молоком, за исключением содержания аргинина и триптофана.

При этом состав заменимых аминокислот всех исследуемых образцов молока сырья имеет схожее соотношение аминокислот с незначительными отклонениями, что в большей степени коррелирует с содержанием общего белка в исследованных образцах (Рисунок 2).

Результаты оценки аминокислотного состава общепринято выражать в мг/г белка или в г/100 г белка по каждой аминокислоте и суммарно, что позволило провести расчет и с учетом содержания ИБ. Полученные результаты исследований, приведенные в Таблице 2 содержания небелковых азотистых веществ (НБА) в диапазоне от $3 \%$ до 10\% позволили осуществить пересчет количественного содержания аминокислот на ИБ. В связи с этим прогнозируемые данные по содержанию аминокислот в готовом продукте могут отличаться от фактических значений.

В Таблице 3 приведены значения содержания заменимых аминокислот в мг/1г белка и мг/1г ИБ.

В Таблице 4 приведены сравнительные результаты исследований содержания незаменимых аминокислот (полноценного белка) в мг/1г белка и мг/1г ИБ.

По результатам проведенных исследований (Таблица 3 и 4) установлено, что при пересчете аминокислот на 1г ИБ содержание заменимых и незаменимых аминокислот пропорционально увеличивается на 1,05-1,08\% по отношению к значениям, вычисляемым с учетом общего белка.

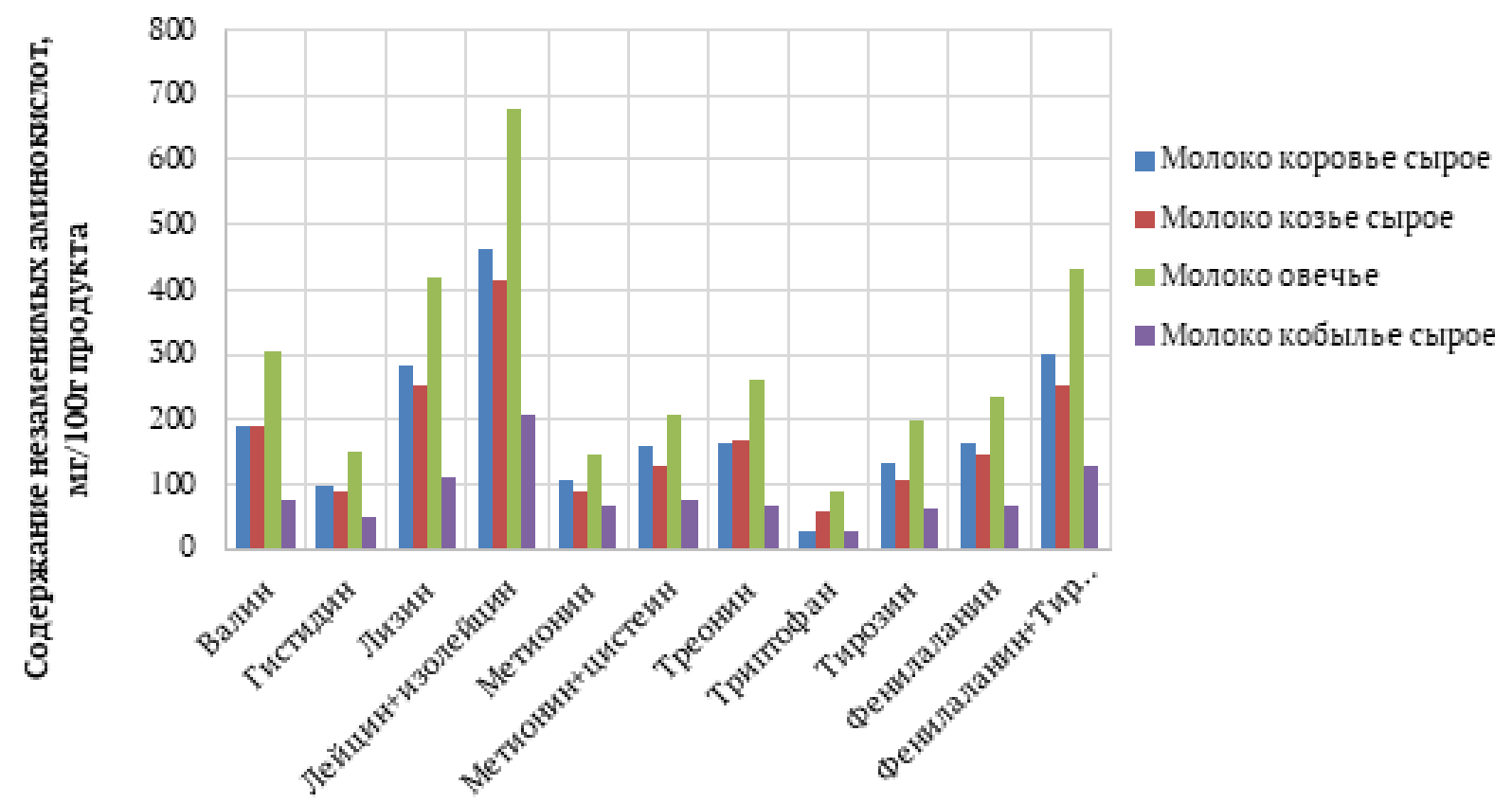

Рисунок 1. Содержание незаменимых аминокислот в молоке сырье различных сельскохозяйственных животных 


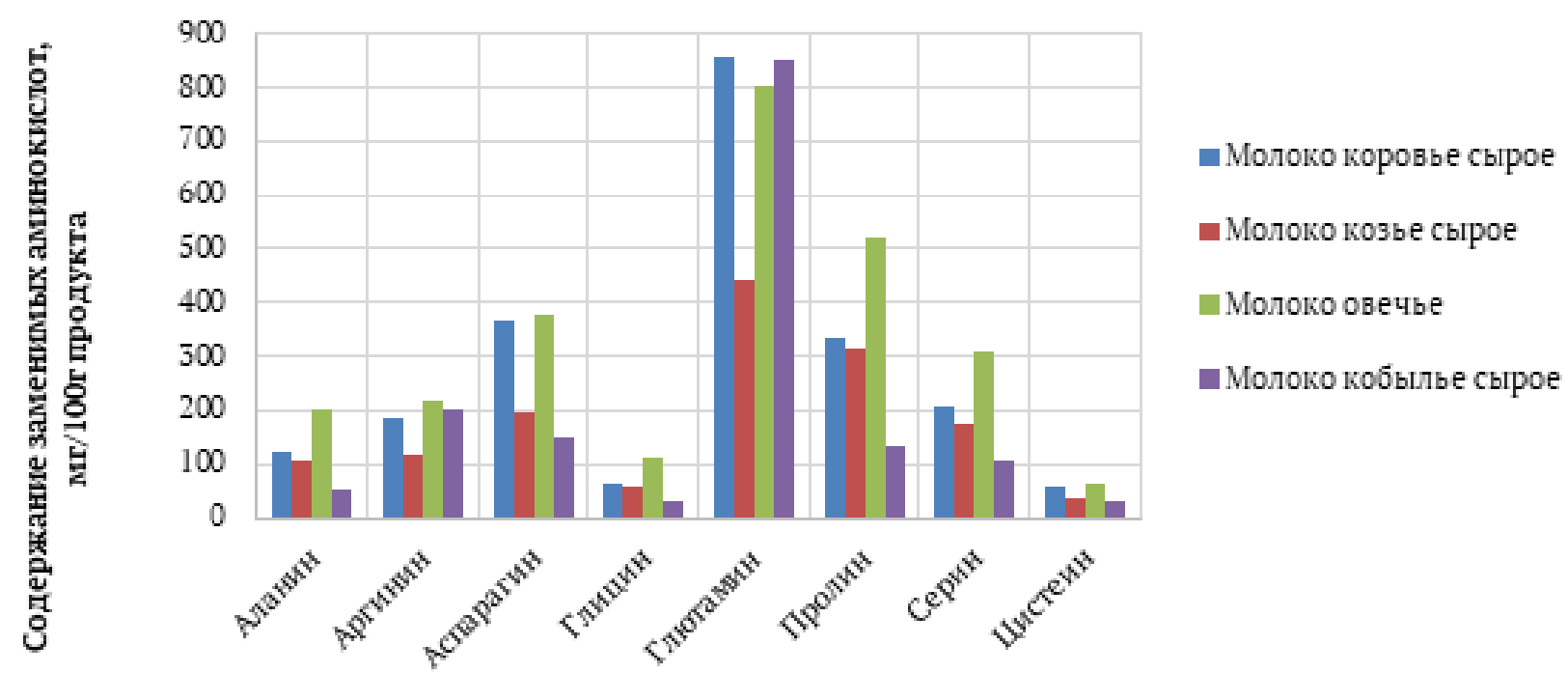

Рисунок 2. Содержание заменимых аминокислот в молоке сырье различных сельскохозяйственных животных

Следовательно, неучтенным остается примерно 1 г полноценного белка. Применяя правильную оценку расчета полноценности белка при подборе молочного сырья, можно не только снизить себестоимость готового продукта, но и не допустить переизбытка или дефицита белка в готовом продукте. Соотношение незаменимых и заменимых аминокислот всех исследованных образцов молока сырья свидетельствуют о сбалансированности аминокислотного состава (содержание незамени-

Таблица 3

Содержание заменимых аминокислот молока сырья, полученного от разных видов сельскохозяйственных животных

\begin{tabular}{|c|c|c|c|c|c|c|c|c|}
\hline \multirow[t]{3}{*}{$\begin{array}{l}\text { Наименование } \\
\text { аминокислоты }\end{array}$} & \multicolumn{2}{|c|}{$\begin{array}{l}\text { Молоко коро- } \\
\text { вье сырое }\end{array}$} & \multicolumn{2}{|c|}{ Молоко козье сырое } & \multicolumn{2}{|c|}{ Молоко овечье сырое } & \multicolumn{2}{|c|}{ Молоко кобылье сырое } \\
\hline & \multicolumn{8}{|c|}{ Содержание аминокислоты, мг/г } \\
\hline & ๕̊ & 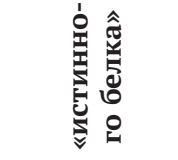 & ๕̊ & 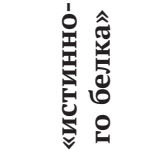 & ๕̊ & 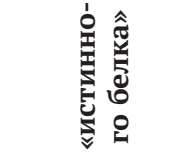 & שัّ & 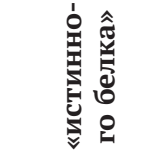 \\
\hline \multicolumn{9}{|c|}{ Заменимые аминокислоты: } \\
\hline Аланин & $35,61 \pm 2,14$ & $37,97 \pm 2,28$ & $28,22 \pm 1,69$ & $30,58 \pm 1,83$ & $40,94 \pm 2,46$ & $44,12 \pm 2,65$ & $23,92 \pm 1,44$ & $25,15 \pm 1,51$ \\
\hline Аргинин & $\begin{array}{c}55,64 \pm \\
3,34\end{array}$ & $\begin{array}{c}59,34^{ \pm} \\
3,56\end{array}$ & $\begin{array}{c}31,33 \pm \\
1,88\end{array}$ & $\begin{array}{c}33,95 \pm \\
2,04\end{array}$ & $\begin{array}{c}44,16^{ \pm} \\
2,65\end{array}$ & $\begin{array}{c}47,59 \pm \\
2,86\end{array}$ & $\begin{array}{c}89,10^{ \pm} \\
5,35\end{array}$ & $\begin{array}{c}93,66^{ \pm} \\
5,62\end{array}$ \\
\hline $\begin{array}{l}\text { Аспарагин + Аспа- } \\
\text { рагиновая кислота }\end{array}$ & $108,69 \pm 6,52$ & $115,92 \pm 6,96$ & $52,93 \pm 3,18$ & $57,35 \pm 3,44$ & $76,03 \pm 4,56$ & $81,94 \pm 4,92$ & $66,25 \pm 3,98$ & $69,64 \pm 4,18$ \\
\hline Глицин & $19,33 \pm 1,16$ & $20,62 \pm 1,24$ & $15,88 \pm 0,95$ & $17,20 \pm 1,03$ & $22,63 \pm 1,36$ & $24,39 \pm 1,46$ & $13,36 \pm 0,80$ & $14,04 \pm 0,84$ \\
\hline $\begin{array}{l}\text { Глютамин +Глута- } \\
\text { миновая кислота }\end{array}$ & $\begin{array}{c}254,01 \pm \\
15,24\end{array}$ & $\begin{array}{c}271,18^{ \pm} \\
16,27\end{array}$ & $117,9 \pm 7,07$ & $\begin{array}{l}127,75 \\
\pm 7,67\end{array}$ & $163,50 \pm 10,37$ & $175,18 \pm 10,51$ & $375,46 \pm 22,53$ & $\begin{array}{c}394,67 \pm \\
23,68\end{array}$ \\
\hline Пролин & $99,82 \pm 5,99$ & $106,46 \pm 6,38$ & $83,59 \pm 5,02$ & $90,58 \pm 5,43$ & $105,36 \pm 6,32$ & $113,55 \pm 6,81$ & $58,80 \pm 3,53$ & $61,81 \pm 3,71$ \\
\hline Серин & $61,87 \pm 3,71$ & $65,98 \pm 3,96$ & $46,64 \pm 2,80$ & $50,55 \pm 3,03$ & $62,31 \pm 3,74$ & $67,15 \pm 4,03$ & $46,31 \pm 2,78$ & $48,67 \pm 2,92$ \\
\hline Цистеин & $\begin{array}{c}16,72 \pm \\
1,00\end{array}$ & $\begin{array}{c}17,81 \pm \\
1,07\end{array}$ & $\begin{array}{c}10,34 \pm \\
0,62\end{array}$ & $\begin{array}{c}11,20^{ \pm} \\
0,67\end{array}$ & $\begin{array}{c}12,66^{ \pm} \\
0,76\end{array}$ & $\begin{array}{c}13,65 \pm \\
81,89\end{array}$ & $\begin{array}{c}13,20 \pm \\
0,79\end{array}$ & $\begin{array}{c}13,88^{ \pm} \\
0,83\end{array}$ \\
\hline $\begin{array}{l}\text { Общее содержа- } \\
\text { ние заменимых } \\
\text { аминокислотот, \% }\end{array}$ & $57,40 \pm 3,44$ & $57,41 \pm 3,44$ & $48,93 \pm 2,94$ & $48,93 \pm 2,94$ & $51,27 \pm 3,08$ & $51,22 \pm 3,07$ & $67,76 \pm 4,07$ & $67,76 \pm 4,07$ \\
\hline
\end{tabular}


Таблица 4

Содержание незаменимых аминокислот молока сырья, полученного от разных видов с/х животных

\begin{tabular}{|c|c|c|c|c|c|c|c|c|}
\hline \multirow[t]{3}{*}{$\begin{array}{l}\text { Наименование } \\
\text { аминокислоты }\end{array}$} & \multicolumn{2}{|c|}{ Молоко коровье сырое } & \multicolumn{2}{|c|}{ Молоко козье сырое } & \multicolumn{2}{|c|}{ Молоко овечье сырое } & \multicolumn{2}{|c|}{$\begin{array}{l}\text { Молоко кобы- } \\
\text { лье сырое }\end{array}$} \\
\hline & \multicolumn{8}{|c|}{ Содержание аминокислоты, мг/г } \\
\hline & שே & 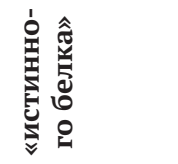 & שே & 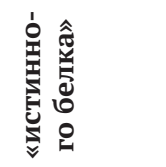 & ๑ே & 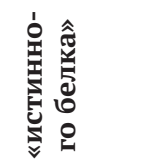 & שี & 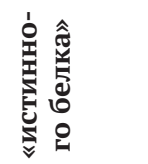 \\
\hline \multicolumn{9}{|c|}{ Незаменимые аминокислоты } \\
\hline Валин & $56,94 \pm 3,30$ & $60,72 \pm 3,64$ & $50,88 \pm 3,05$ & $55,13 \pm 3,31$ & $61,47 \pm 3,69$ & $66,24 \pm 3,97$ & $33,41 \pm 2,00$ & $35,12 \pm 2,11$ \\
\hline Гистидин & $28,75 \pm 1,73$ & $30,66 \pm 1,84$ & $24,26 \pm 1,46$ & $26,29 \pm 1,58$ & $30,29 \pm 1,82$ & $32,64 \pm 1,96$ & $21,64 \pm 1,30$ & $22,74 \pm 1,36$ \\
\hline Лизин & $84,01 \pm 5,04$ & $89,59 \pm 5,38$ & $66,78 \pm 4,01$ & $72,36 \pm 4,34$ & $85,12 \pm 5,11$ & $91,74 \pm 5,50$ & $48,67 \pm 2,92$ & $51,16 \pm 3,07$ \\
\hline $\begin{array}{l}\text { Лейцин + } \\
\text { Изолейцин }\end{array}$ & $137,45 \pm 8,25$ & $146,58 \pm 8,79$ & $110,51 \pm 6,63$ & $119,74 \pm 7,18$ & $137,00 \pm 8,22$ & $147,64 \pm 8,86$ & $91,65 \pm 5,50$ & $96,34 \pm 5,78$ \\
\hline Метионин & $31,31 \pm 1,88$ & $33,39 \pm 2,00$ & $23,93 \pm 1,44$ & $25,93 \pm 1,56$ & $29,18 \pm 1,75$ & $31,45 \pm 1,89$ & $30,11 \pm 1,81$ & $31,65 \pm 1,90$ \\
\hline $\begin{array}{l}\text { Метионин + } \\
\text { Цистеин }\end{array}$ & $48,03 \pm 2,88$ & $51,22 \pm 3,07$ & $34,27 \pm 2,06$ & $37,13 \pm 2,23$ & $41,85 \pm 2,51$ & $45,10 \pm 2,71$ & $43,29 \pm 2,60$ & $45,53 \pm 2,73$ \\
\hline Треонин & $48,19 \pm 2,89$ & $51,39 \pm 3,08$ & $44,89 \pm 2,69$ & $48,65 \pm 2,92$ & $52,97 \pm 3,18$ & $57,07 \pm 3,42$ & $30,85 \pm 1,85$ & $32,42 \pm 1,95$ \\
\hline Триптофан & $8,10 \pm 0,49$ & $8,63 \pm 0,52$ & $15,12 \pm 0,91$ & $16,39 \pm 0,98$ & $18,28 \pm 1,10$ & $19,70 \pm 1,18$ & $12,64 \pm 0,76$ & $13,28 \pm 0,80$ \\
\hline Тирозин & $39,76 \pm 2,39$ & $42,41 \pm 2,54$ & $28,56 \pm 1,71$ & $30,95 \pm 1,86$ & $40,07 \pm 2,40$ & $43,19 \pm 2,59$ & $27,56 \pm 1,65$ & $28,97 \pm 1,74$ \\
\hline Фенилаланин & $49,20 \pm 2,95$ & $52,47 \pm 3,15$ & $38,88 \pm 2,33$ & $42,13 \pm 2,53$ & $47,14 \pm 2,83$ & $50,80 \pm 3,05$ & $30,11 \pm 1,81$ & $31,62 \pm 1,90$ \\
\hline $\begin{array}{l}\text { Фенилала- } \\
\text { нин+Тирозин }\end{array}$ & $88,96 \pm 5,34$ & $94,87 \pm 5,64$ & $67,45 \pm 4,05$ & $73,08 \pm 4,39$ & $87,21 \pm 5,23$ & $93,99 \pm 5,64$ & $57,67 \pm 3,46$ & $60,62 \pm 3,64$ \\
\hline $\begin{array}{l}\text { Общее содержа- } \\
\text { ние заменимых } \\
\text { аминокислотот, \% }\end{array}$ & $42,60 \pm 2,56$ & $42,59 \pm 2,56$ & $51,07 \pm 3,06$ & $51,07 \pm 3,06$ & $48,73 \pm 2,92$ & $48,78 \pm 2,93$ & $32,24 \pm 1,94$ & $32,24 \pm 1,93$ \\
\hline
\end{tabular}

мых аминокислот от общего содержания аминокислот составляет от $32,24 \%$ у кобыльего молока до $51,07 \%$ у козьего молока).

Для определения биологической (пищевой ценности) белка молока сырого провели сравнительную оценку аминокислотного состава исследуемых образцов молока по отношению к эталонному белку. Полученные результаты исследований приведены

Как видно из Рисунка 3 скор лимитирующей незаменимой аминокислоты коровьего молока - 95,3\% (триптофан), а скор кобыльего молока характеризуется несколькими незаменимыми аминокислотами, в частности валин, лизин, лейцин + изолейцин (100\%), наименьшая - 77,7\% (валин). Аминокислотный состав молока козьего и овечьего отличался отсутствием лимитирующих аминокислот, а минимальный скор составил 139,8\% (лизин) и 106,6\% (лейцин + изолейцин), соответственно. Отмечено, что высокие значения ами- нокислотного скора у белков овечьего, коровьего и козьего молока, максимальный скор которых $215,1 \%$ (триптофан), 177,9\% (метионин + цистеин) и $177,9 \%$ (триптофан) соответственно. Установлено, что по составу незаменимых аминокислот наиболее приближенным к «эталонному» (идеальному) оказался белок козьего молока, в котором не зафиксировано очень резких отклонений от установленных норм.

Для дальнейшего обоснования использования молока различных видов сельскохозяйственных животных в качестве основного компонента при производстве функциональных продуктов питания рассчитали показатели биологической полноценности или качественной оценки белка (Образов, Надточий, Сафронова, 2019; Липатов, Рогов, 1987):

- коэффициент различий (разбалансированности) аминокислотного скора (КРАС);

- показатель биологической ценности (БЦ),\%; 


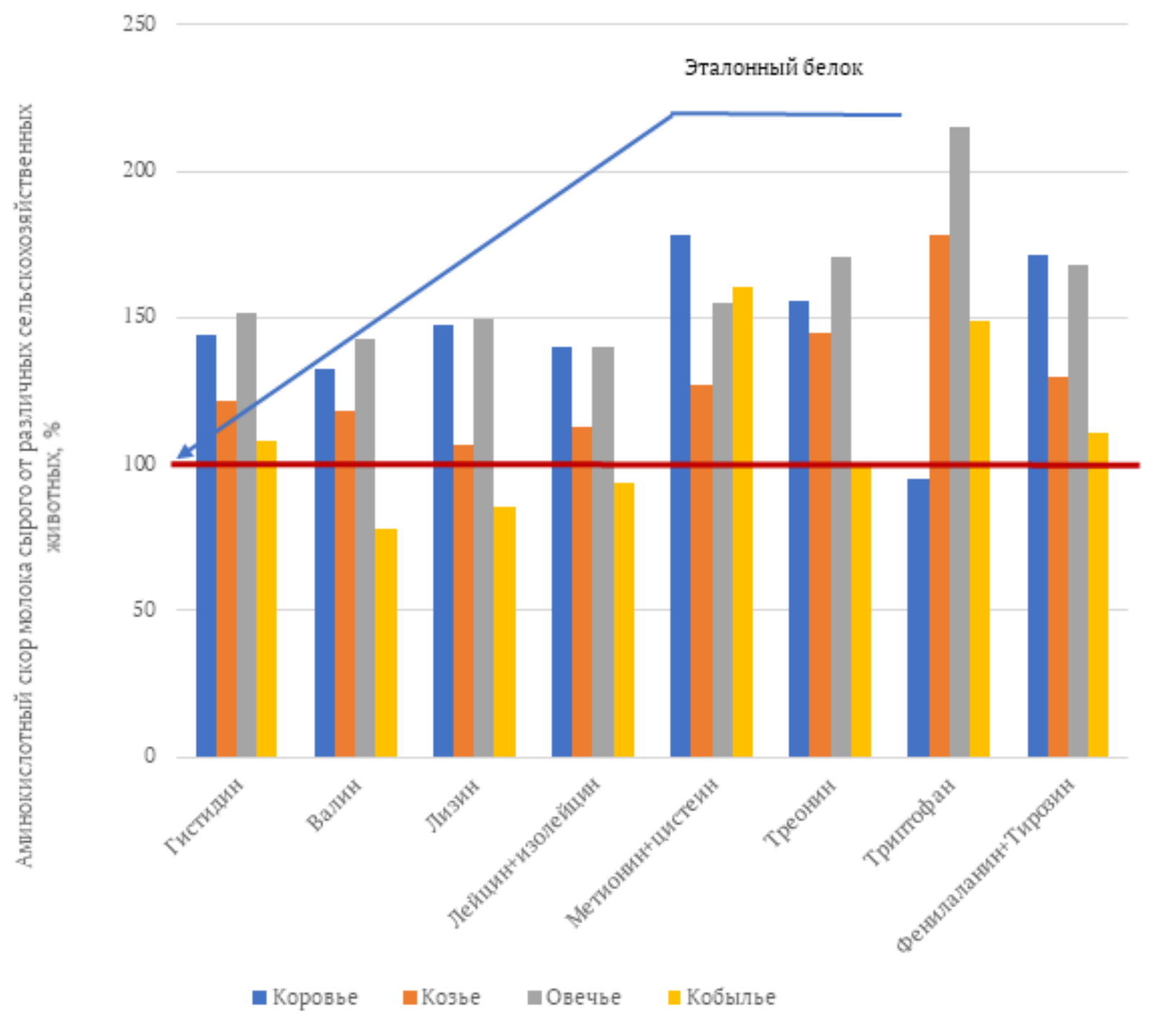

Рисунок 3. Сравнительная оценка аминокислотного состава исследуемых образцов молока по отношению к эталонному белку

Расчет коэффициента различий аминокислотного скора (КРАС), который устанавливает разбалансированность аминокислотного состава относительно эталонного белка проводили по формуле (2)

$\mathrm{KPAC}=\Sigma \Delta \mathrm{PAC} / \mathrm{n}$

где: $\triangle P A C$ - различие аминокислотного скора аминокислоты вычисляется по формуле (3); $n$ - количество незаменимых аминокислот.

$\triangle P A C=C i-C \min$

где: $C_{\mathrm{i}}-$ скор $i$-той незаменимой аминокислоты,\%; $C_{\min }-$ минимальный из скоров незаменимых аминокислот (скор лимитирующей аминокислоты),\%:
Биологическую ценность (БЦ) пищевого белка определяли по формуле (4):

$Б Ц=100-K P A C, \%$

Полученные результаты расчетов качественного состава белков исследованных образцов молока сырого приведены в Таблице 5.

Исходя из полученных результатов, приведенных в Таблице 5 следует, что наибольшее содержание общего белка зафиксировано у овечьего $(5,16 \%)$ и козьего молока (3,76\%), немногим меньше содержание в коровьем молоке (3,37\%) и самым низким содержанием массовой доли белка характеризуется кобылье молоко (2,26\%). Также отмечено отсутствие в аминокислотном составе белков козьего и овечьего молока незаменимых аминокислот, ли- 
Таблица 5

Показатели качественного состава белка молока сырья разных видов сельскохозяйственных животных

\begin{tabular}{|c|c|c|c|c|}
\hline \multirow[t]{2}{*}{ Наименование показателя } & \multicolumn{4}{|c|}{ Молоко сырое } \\
\hline & Коровье & Козье & Овечье & Кобылье \\
\hline Массовая доля белка, \% & 3,37 & 3,76 & 5,16 & 2,26 \\
\hline $\begin{array}{l}\text { Содержание лимитирующей } \\
\text { незаменимой аминокисло- } \\
\text { ты (НАК), г/100г белка }\end{array}$ & 0,95 & $1,07^{*}$ & $1,49 *$ & 0,78 \\
\hline $\begin{array}{l}\text { Коэффициент различия амино- } \\
\text { кислотного скора (КРАС), \% }\end{array}$ & 1,53 & 1,22 & 1,16 & 1,42 \\
\hline $\begin{array}{l}\text { Показатель биологической ценности } \\
\text { (БЦ), \% }\end{array}$ & 98,47 & 98,78 & 98,85 & 98,58 \\
\hline
\end{tabular}

*При расчете коэффициентов и показателей качества белков молока овечьего и козьего, у которых не выявлено незаменимых аминокислот (НАК) со скорами ниже 100\%, за условно лимитирующие принимали НАК с наименьшими значениями.

митирующих биологическую ценность белка. Полученные данные по показателям биологической ценности исследованных образцов молока сырого позволили сделать вывод, что молоко разных видов сельскохозяйственных животных имеет высокие значения показателей биологической ценности и рекомендуется для производства продуктов функциональной направленности.

\section{Выводы}

Комплексный подход к оценке функциональной полноценности белкового состава молока сырого, полученного от разных видов с/х животных показал, что все виды молока сырья могут быть применены в качестве одного из основных сырьевых компонентов при производстве продуктов функциональной направленности, в том числе и от дифференцирования по группам потребителей и их физиологической потребности в белке.

Молоко кобылье может быть рекомендовано, как основной сырьевой компонент при производстве продуктов детского питания.

Качественная и количественная оценка белкового состава молочного сырья в пересчете на ИБ позволит получить достоверные результаты по содержанию «технологического» белка и его биологической полноценности, а также минимизировать потери полноценного белка в процессе производства многокомпонентных функциональных продуктов. Использование предложенного алгоритма оценки незаменимых аминокислот в пересчете на истинный белок позволит получить продукт со стабильными, прогнозируемыми функциональными свойствами.

\section{Литература}

Агаркова Е.Ю., Кручинин А.Г., Рязанцева К.А., Пряничникова Н.С. Ферментативная обработка как инструмент придания функциональных свойств белкам молочной сыворотки // Аграрнопищевые инновации. 2019. № 4(8). с. 81-88. https://doi.org/10.31208/2618-7353-2019-8-81-88

Асембаева Э.К., Галстян А.Г., Хуршудян С.А., Нурмуханбетова Д.Е., Велямов М.Т., Аленова А.Б., Сейдахметова 3.Ж. Разработка технологии и исследование иммунобиологических свойств кисломолочного напитка на основе верблюжьего молока // Вопросы питания. 2017. Т. 86, № 6. с. 6773. https://doi.org/10.24411/0042-8833-2017-00007 Бабич О.Р. Исследование и разработка технологии молочного белкового эквивалента для специализированных продуктов питания: дис. ... канд. техн. наук: 05.15.04. Кемерово, 2009. 186 с.

Бахтиярова Л.Р. Разработка продуктов здорового питания на основе кобыльего молока // Достижения химии в агропромышленном комплексе: материалы II Всероссийской молодежной конференции-школы с международным участием. Уфа, 2016. с. 96-99.

Бушуева Т.В. Современный взгляд на проблему фенилкетонурии у детей: диагностика, клиника, лечение // Вопросы современной педиатрии 2010. T. 9, № 1. с. 157-160.

Галстян А.Г., Аксёнова Л.М., Лисицын А.Б., Оганесянц Л.А., Петров А.Н. Современные подходы к хранению и эффективной переработке сельскохозяйственной продукции для получения 
высококачественных пищевых продуктов // Вестник Российской академии наук. 2019. Т. 89, № 5. с. 539-542. https://doi.org/10.31857/S08695873895539-542

Донская Г.А. Функциональные молочные продукты // Молочная промышленность. 2007. № 3. c. $52-53$.

Зобкова 3.С. Цельномолочные продукты, обогащённые функциональными ингредиентами и пищевыми добавками // Молочная промышленность. 2007. № 10. с. 75-76.

Зобкова 3.С., Фурсова Т.П., Зенина Д.В. Выбор белковых ингредиентов, обогащающих и модифицирующих структуру кисломолочных напитков // Актуальные вопросы индустрии напитков. 2018. № 2. с. 64-69. https://doi. org/10.21323/978-5-6041190-3-7-2018-2-64-69

Кручинин А.Г., Агаркова Е.Ю. Различные подходы к формированию функциональных свойств молочных продуктов // Переработка молока. 2018. № 5(223). с. 36-39.

Лепешкин А.И., Надточий Л.А., Чечеткина А.Ю. Проектирование состава продуктов питания с заданными свойствами. СПб: Университет ИТМО, 2020. 46 с.

Липатов Н.Н. Принципы и методы проектирования рецептур пищевых продуктов, балансирующих рационы питания // Известия вузов. Пищевая технология. 1990. № 6. с. 5-10.

Липатов Н.Н., Рогов И.А. Методология проектирования продуктов питания с требуемым комплексом показателей пищевой ценности // Известия вузов. Пищевая технология. 1987. № 2. c. 9-15.

Литвицкий П.Ф., Мальцева Л.Д. Нарушения обмена белков, аминокислот и нуклеиновых кислот // Вопросы современной педиатрии. 2015. Т. 14, № 1. с. 95-107. https://doi.org/10.15690/vsp. v14i1.1267

Лысиков Ю.А. Аминокислоты в питании человека // Экспериментальная и клиническая гастроэнтерология. 2012. № 2. С.88-105.

Малиновский А.В. Является ли треонин незаменимой аминокислотой для человека? // Профилактическая и клиническая медицина. 2011. № 4(41). с. 116-119.

Молчанова Е.Н., Суслянок Г.М. Оценка качества и значение пищевых продуктов // Хранение и переработка сельхозсырья. 2013. № 1. с. 16-22.

Нечаева Г.И., Друк И.В., Лялюкова Е.А. Белковоэнергетическая недостаточность в клинической практике // Экспериментальная и клиническая гастроэнтерология. 2013. № 7. с. 23-26.

Образов А., Надточий Л.А., Сафронова А.В. Оценка биологической ценности молока сельскохозяйственных животных // Техника и технология пищевых производств. 2019. Т. 49, № 3. С 447453. https://doi.org/10.21603/2074-9414-2019-3447-453

Рудаков О.Б., Рудакова Л.В. Аминокислотный анализ белков молока // Переработка молока. 2019. № 12(242). c. 32-35. https://doi.org/10.33465/23082941-2020-2-29-35

Федотова О.Б., Донская Г.А., Рожкова И.В., Асафов В.А., Добриян Е.А., Чумакова И.В. Разработки ВНИМИ в области создания нового поколения функциональных продуктов // Сборник материалов международной научно-практической конференции. 2016. с. 15-18.

Фильчакова С.А., Медведев Е.В., Тамбовцев Ю.Н. Экологически безопасные продукты с функциональными свойствами // Экологические системы и приборы. 2006. № 8. с. 42-44.

Хамагаева И.С., Хараев Г.И., Жеребятьева О.А., Щёкотова А.В. Исследование аминокислотного состава белкового продукта на основе козьего молока, ферментированного Lactobacillus helveticus 3 5-1 // Вестник ВСГУТУ. 2015. № 1(52). с. 72-77.

Шувариков А.С., Пастух О.Н., Жукова Е.В., Жижин Н.А. Оценка молочной продуктивности и качества молока коз в зависимости от породы и генотипа по гену blg (бета-лактоглобулина) // Известия Тимирязевской сельскохозяйственной академии. 2019. № 3. с. 130-148. https://doi. org/10.34677/0021-342X-2019-3-130-148

Шувариков А.С., Хататаев С.А., Пастух О.Н., Робкова T.О., Семенова Е.С., Коробейник Е.С. Физикохимические и технологические показатели молока овец восточно-фризской породы при разведении их в центральной России // Овцы, козы, шерстяное дело. 2019. № 3. с. 30-32.

Юрова Е.А., Денисович Е.Ю., Кобзева Т.В., Мельденберг Д.Н., Семёнова Е.С., Жижин Н.А., Пахомова Н.А. Объективная оценка заданных свойств продукта // Молочная промышленность. 2019. № 10. с. 50-53.

Юрова Е.А., Кобзева Т.В., Полякова О.С. Разработка методов оценки хранимоспособности молочной продукции // Переработка молока. 2016. № 12. с. 38-41.

Юрова Е.А., Семенова Е.С., Мельденберг Д.Н., Канина К.А., Робкова Т.О. Сравнительная оценка молока-сырья жвачных сельскохозяйственных животных // Молочная промышленность. 2017. № 8. c. 60-63.

Augustin M.A., Udabage P. Influence of processing on functionality of milk and dairy proteins. Advances in Food and Nutrition Research. 2007. Vol. 53. P. 1-38. https://doi.org/10.1016/S1043-4526(07)53001-9

Dziuba B., Dziuba M. Milk proteins-derived bioactive peptides in dairy products: molecular, biological 
and methodological aspects // Acta Scientiarum Polonorum. Technologia Alimentaria. 2014. Issue 13(1). P. 5-26. https://doi.org/10.17306/J. AFS.2014.1.1

Kinsella J., Melachouris N. Functional properties of proteins in foods: a survey // CRC Critical Reviews in Food Science and Nutrition. 1976. Vol. 7, issue 3. P. 219-280. https://doi. org/10.1080/10408397609527208

Kristo E., Corredig, M. Functional properties of food proteins // Applied Food Protein Chemistry / Z. Ustunol. Hoboken: John Wiley \& Sons, Ltd, 2015. P. 47-73. https://doi.org/10.1002/9781118860588. ch5

Mattila-Sandholm T., Saarela M. Functional dairy products // Woodhead Publishing Series in Food Science, Technology and Nutrition. 2003. Vol. 1. P. 11-13. https://doi.org/10.1016/B978-1-85573584-2.50004-3
Ryan D.S. Determinants of functional properties of proteins and protein derivatives in foods // Food Proteins. Improvement Through Chemical and Enzymatic Modification / R.F. Feeney, J.R. Whitaker. Washington. DC: American Chemical Society, 1977. P. 67-91. https://doi.org/10.1021/ba1977-0160.ch004

Singh H. Functional properties of milk proteins // Encyclopedia of Dairy Sciences / J.W. Fuquay. 2nd ed. Amsterdam: Elsevier Ltd, 2011. P. 887893. https://doi.org/10.1016/B978-0-12-3744074.00352-6

Wilding P., Lillford P., Regenstein J. Functional properties of proteins in foods // Journal of Chemical Technology and Biotechnology. 2008. Vol. 34, issue 3. P. 182-189. https://doi.org/10.1002/jctb.280340307

Zdzislaw E. Sikorski chemical and functional properties of food proteins. CRC Press, 2001. 504 P. https://doi.org/10.1201/9781482279047 


\title{
Development of a Comprehensive Milk Protein Composition Assessment from Raw Materials of Various Farm Animals for the Functional Products Production
}

\author{
Daria N. Meldenberg \\ FGANU “All-Russian Dairy Research Institute “ \\ 35/7 Lyusinovskaya st., Moscow, 115093, Russian Federation \\ E-mail:d_meldenberg@vnimi.org
}

Olga S. Polyakova FGANU “All-Russian Dairy Research Institute “ 35/7 Lyusinovskaya st., Moscow, 115093, Russian Federation E-mail:o_polyakova@vnimi.org Elena S. Semenova

Elena S. Semenova FGANU “All-Russian Dairy Research Institute " 35/7 Lyusinovskaya st., Moscow, 115093, Russian Federation E-mail: e_semenova@vnimi.org

Elena A. Yurova FGANU “All-Russian Dairy Research Institute “ 35/7 Lyusinovskaya st., Moscow, 115093, Russian Federation E-mail:e_yurova@vnimi.org

\begin{abstract}
Recently, food products manufacture with increased biological value, with new composite ingredients and functional characteristics due to both the composition of the components and the raw materials used, has acquired considerable interest. For manufacturing these products, the selection of the optimal raw milk is required with a mandatory assessment of the amount of protein, its composition and usefulness, that was done in this research and considered raw milk from various farm animals. During this study, as research methods, both generally accepted and standardized control methods and improved measurement techniques were used, in particular, the method of capillary electrophoresis (CEF) was used to determine the amino acid composition. According to the research results, the dependence of the content of the mass fraction of protein on the content of non-protein nitrogenous substances, true protein, essential and nonessential amino acids has been found. The necessity of determining the true protein to consider the usefulness of the protein in the finished product was noted. It was found that during recalculation the amount of amino acids $\mathrm{mg} / \mathrm{g}$ for the content of true protein the amount of essential and nonessential amino acids is proportionally increased by $1.05-1.08 \%$ in comparison with the conversion to the total protein content, i.e. approximately $1 \mathrm{~g}$ of complete milk protein remains unaccounted for.
\end{abstract}

Keywords: raw milk, mass fraction of protein, non-protein nitrogen, true protein, amino acid composition, amino acid rate, biological value, functional properties

\section{References}

Agarkova E.Ju., Kruchinin A.G., Rjazanceva K.A., Prjanichnikova N.S. Fermentativnaja obrabotka kak instrument pridanija funkcional'nyh svojstv belkam molochnoj syvorotki [Enzymatic processing as a tool of giving functional properties to proteins of milk serum]. Agrarno-pishhevye inno- vacii [Agrian-and-food innovations], 2019, no. 4(8), pp. 81-88. https://doi.org/10.31208/2618-73532019-8-81-88

Asembaeva Je.K., Galstjan A.G., Hurshudjan S.A., Nurmuhanbetova D.E., Veljamov M.T., Alenova A.B., Sejdahmetova Z.Zh. Razrabotka tehnologii i issledovanie immunobiologicheskih svojstv kislomolochnogo napitka na osnove verbljuzh'ego 
moloka [Development of technology and research of immunobiological properties of fermented milk drink based on camel milk].Voprosy pitanija [Nutrition issues], 2017, vol. 86, no. 6, pp. 67-73. https://doi.org/10.24411/0042-8833-2017-00007

Augustin MA, Udabage P. Influence of processing on functionality of milk and dairy proteins. Advances in Food and Nutrition Research, 2007, vol. 53. pp. 1-38. https://doi.org/10.1016/S10434526(07)53001-9

Babich O.R. Issledovanie i razrabotka tehnologii molochnogo belkovogo jekvivalenta dlja specializirovannyh produktov pitanija. Diss. kand. texn. nauk [Research and development of milk protein equivalent technology for specialized foods. Ph.D. (Technology) thesis]. Kemerovo,2009, 186 p.

Bahtijarova L.R. Razrabotka produktov zdorovogo pitanija na osnove kobyl'ego moloka [Development of healthy nutrition products based on mare's milk]. In Dostizhenija himii v agropromyshlennom komplekse: materialy II Vserossijskoj molodezhnoj konferencii-shkoly s mezhdunarodnym uchastiem [School with international participation: materials of the 2nd All-Russian Youth Conference]. Ufa, 2016, pp. 96-99.

Bushueva T.V. Sovremennyj vzgljad na problemu fenilketonurii u detej: diagnostika, klinika, lechenie [A modern look at the problem of phenylketonuria in children: diagnosis, clinic, treatment]. Voprosy sovremennoj pediatrii [Questions of modern pediatrics], 2010, vol. 9, no. 1, pp. 157-160.

Donskaja G.A. Funkcional'nye molochnye produkty [Functional Dairy Products] // Molochnaja promyshlennost [Dairy industry], 2007, no. 3, pp. 52-53.

Fedotova O.B., Donskaja G.A., Rozhkova I.V., Asafov V.A., Dobrijan E.A., Chumakova I.V. Razrabotki VNIMI v oblasti sozdanija novogo pokolenija funkcional'nyh produktov [VNIMI developments in the field of creating a new generation of functional products]. Sbornik materialov mezhdunarodnoj nauchno-prakticheskoj konferencii [Collection of materials of the international scientific-practical conference], 2016, pp. 15-18.

Filchakova S.A., Medvedev E.V., Tambovcev Ju.N. Jekologicheski bezopasnye produkty s funkcional'nymi svojstvami [Environmentally friendly products with functional properties]. Jekologicheskie sistemy $i$ pribory [Ecological systems and devices], 2006, no. 8. pp. 42-44.

Galstjan A.G., Aksjonova L.M., Lisicyn A.B., Oganesjanc L.A., Petrov A.N. Sovremennye podhody k hraneniju i jeffektivnoj pererabotke sel'skohozjajstvennoj produkcii dlja poluchenija vysokokachestvennyh pishhevyh produktov [Modern approaches to the storage and efficient processing of agricultural products to obtain high-quality food products]. Vestnik Rossijskoj akademii nauk [Bulletin of the Russian Academy of Sciences], 2019, vol. 89, no. 5, pp. 539-542. https:// doi.org/10.31857/S0869-5873895539-542

Hamagaeva I.S., Haraev G.I., Zherebjat'eva O.A., Shhjokotova A.V. Issledovanie aminokislotnogo sostava belkovogo produkta na osnove koz'ego moloka, fermentirovannogo lactobacillus helveticus 3 5-1 [The study of the amino acid composition of a protein product based on goat milk fermented by lactobacillus helveticus 3 5-1]. Vestnik ESSUTM [ESSUTM Bulletin], 2015, no. 1(52), pp. 72-77.

Jurova E.A., Kobzeva T.V., Polyakova O.S. Razrabotka metodov ocenki hranimosposobnosti molochnoj produkcii [Development of methods for assessing the storage capacity of dairy products]. Pererabotka moloka [Milk processing], 2016, no. 12, pp. 38-41.

Jurova E.A., Denisovich E.Ju., Kobzeva T.V., Mel'denberg D.N., Semjonova E.S., Zhizhin N.A., Pahomova N.A. Obektivnaja ocenka zadannyh svojstv produkta [Objective assessment of desired product properties]. Molochnaja promyshlennost [Dairy industry], 2019, no. 10, pp. 50-53.

Jurova E.A., Semenova E.S., Mel'denberg D.N., Kanina K.A., Robkova T.O. Sravnitel'naja ocenka moloka-syr'ja zhvachnyh sel'skohozjajstvennyh zhivotnyh [Comparative evaluation of raw milk of ruminant farm animals]. Molochnaja promyshlennost [Dairy industry], 2017, no. 8. pp. 60-63.

Kruchinin A.G., Agarkova E.Ju. Razlichnye podhody k formirovaniju funkcional'nyh svojstv molochnyh produktov [Various approaches to the formation of the functional properties of dairy products]. Pererabotka moloka [Milk processing], 2018, no. 5(223), pp. 36-39.

Lepeshkin A.I., Nadtochij L.A., Chechetkina A.Ju., Proektirovanie sostava produktov pitanija $\mathrm{s}$ zadannymi svojstvami [Designing the composition of food products with desired properties]. S-Petersburg: Universitet ITMO, 2020.46 p.

Lipatov N.N. Principy i metody proektirovanija receptur pishhevyh produktov, balansirujushhih raciony pitanija [Principles and methods for designing recipes that balance diets]. Izvestija vuzov. Pishevaja tehnologija [University News. Food technology], 1990, no. 6, pp. 5-10.

Lipatov N.N., Rogov I.A. Metodologija proektirovanija produktov pitanija s trebuemym kompleksom pokazatelej pishhevoj cennosti [The methodology of designing food products with the required set of indicators of nutritional value]. Izvestija vuzov. Pishhevaja tehnologija [University News. Food technology], 1987, no. 2, pp. 9-15.

Litvickij P.F., Mal'ceva L.D. Narushenija obmena belkov, aminokislot i nukleinovyh kislot [Disruptions in the exchange of proteins, amino acids and nucleic acids]. 
Voprosy sovremennoj pediatrii [Questions of modern pediatrics], 2015, vol. 14, no. 1. pp. 95-107. https:// doi.org/10.15690/vsp.v14i1.1267

Lysikov Ju.A. Aminokisloty v pitanii cheloveka [Amino acids in human nutrition]. Jeksperimental'naja $i$ klinicheskaja gastrojenterologija [Experimental and clinical gastroenterology], 2012, no. 2, pp.88-105.

Malinovskij A.V. Javljaetsja li treonin nezamenimoj aminokislotoj dlja cheloveka? [Is threonine an essential amino acid for humans?]. Profilakticheskaja $i$ klinicheskaja medicina [Preventive and clinical medicine], 2011, no. 4(41), pp. 116-119.

Molchanova E.N., Susljanok G.M. Ocenka kachestva i znachenie pishhevyh produktov [Evaluation of the quality and importance of food]. Hranenie $i$ pererabotka sel'hozsyr'ja [Storage and Processing of Farm Products], 2013, no. 1, pp. 16-22.

Nechaeva G.I., Druk I.V., Ljaljukova E.A. Belkovojenergeticheskaja nedostatochnost' $\mathrm{v}$ klinicheskoj praktik e [Protein-energy deficiency in clinical practice]. Jeksperimental'naja i klinicheskaja gastrojenterologija [Experimental and clinical gastroenterology], 2013, no. 7, pp. 23-26.

Obrazov A., Nadtochij L.A., Safronova A.V. Ocenka biologicheskoj cennosti moloka sel'skohozjajstvennyh zhivotnyh [Assessment of the biological value of milk of farm animals]. Tehnika i tehnologija pishhevyh proizvodstv [Technique and technology of food production], 2019, vol. 49, no. 3, pp. 447-453. https://doi. org/10.21603/2074-9414-2019-3-447-453

Rudakov O.B., Rudakova L.V. Aminokislotnyj analiz belkov moloka [Amino acid analysis of milk proteins]. Pererabotka moloka [Milk processing], 2019, no. 12(242), pp. 32-35. https://doi.org/10.33465/23082941-2020-2-29-35

Shuvarikov A.S., Hatataev S.A., Pastuh O.N., Robkova T.O., Semenova E.S., Korobejnik E.S. Fizikohimicheskie i tehnologicheskie pokazateli moloka ovec vostochno-frizskoj porody pri razvedenii ih v central'noj Rossii [Physico-chemical and technological parameters of milk of sheep of the East Frisian breed when they are bred in central Russia. Ovcy, kozy, sherstjanoe delo [Sheep, goats, wool], 2019, no. 3, pp. 30-32.

Shuvarikov A.S., Pastuh O.N., Zhukova E.V., Zhizhin N.A. Ocenka molochnoj produktivnosti i kachestva moloka koz $\mathrm{v}$ zavisimosti ot porody i genotipa po genu blg (beta-laktoglobulina) [Assessment of milk productivity and quality of goat milk depending on breed and genotype by blg gene (beta-lactoglobulin)]. Izvestija Timirjazevskoj sel'skohozjajstvennoj akademii [Bulletin of the Timiryazev Agricultural Academy], 2019, no. 3, pp. 130-148. https://doi. org/10.34677/0021-342X-2019-3-130-148
Zobkova Z.S. Cel'nomolochnye produkty, obogashhjonnye funkcional'nymi ingredientami i pishhevymi dobavkami [Whole milk products enriched with functional ingredients and nutritional supplements]. Molochnaja promyshlennost [Dairy industry], 2007, no. 10, pp. 75-76.

Zobkova Z.S., Fursova T.P., Zenina D.V. Vybor belkovyh ingredientov, obogashhajushhih i modificirujushhih strukturu kislomolochnyh napitkov [The choice of protein ingredients that enrich and modify the structure of fermented milk drinks]. Aktual'nye voprosy industrii napitkov [Actual issues of the beverage industry], 2018, no. 2, pp. 6469. https://doi.org/10.21323/978-5-6041190-3-72018-2-64-69

Dziuba B., Dziuba M. Milk Proteins-Derived Bioactive Peptides in Dairy Products: Molecular, Biological and Methodological Aspects. Acta Scientiarum Polonorum. Technologia Alimentaria, 2014, issue 13(1), pp. 5-26. https://doi.org/10.17306/J.AFS.2014.1.1

Kinsella J., Melachouris N. Functional Properties of Proteins in Foods: A Survey. CRC Critical Reviews in Food Science and Nutrition, 1976, vol. 7, issue 3, pp. 219-280. https://doi.org/10.1080/ 10408397609527208

Kristo E., Corredig, M. Functional Properties of Food Proteins. In Z. Ustunol (ed.) Applied Food Protein Chemistry. Hoboken: John Wiley \& Sons, Ltd, 2015. pp. 47-73. https://doi.org/10.1002/9781118860588. ch5

Mattila-Sandholm T., Saarela M. Functional Dairy Products. Woodhead Publishing Series in Food Science, Technology and Nutrition, 2003, vol. 1, pp. 47-73. https://doi.org/10.1016/B978-1-85573584-2.50004-3

Ryan. D.S. Determinants of Functional Properties of Proteins and Protein Derivatives in Foods. In R.F. Feeney, J.R. Whitaker (eds.). Food Proteins. Improvement Through Chemical and Enzymatic Modification. Washington. DC: American Chemical Society, 1977, pp. 67-91. https://doi.org/10.1021/ ba-1977-0160.ch004

Singh H. Functional Properties of Milk Proteins. In J.W. Fuquay (ed.) Encyclopedia of Dairy Sciences. 2nd ed. Amsterdam: Elsevier Ltd, 2011, pp. 887-893. https:// doi.org/10.1016/B978-0-12-374407-4.00352-6

Wilding P., Lillford P., Regenstein J. Functional Properties of Proteins in Foods. Journal of Chemical Technology and Biotechnology, 2008, vol. 34, issue 3, pp. 182-189. https://doi.org/10.1002/ jctb. 280340307

Zdzislaw E. Sikorski Chemical and Functional Properties of Food Proteins. CRC Press, 2001, 504 P. https://doi.org/10.1201/9781482279047 